\title{
Fixed Segmentism in Palauan Multiple Reduplications
}

\author{
Tomoko Kawamura \\ State University of New York at Stony Brook
}

\section{Introduction}

Palauan is a language with two reduplicative morphemes, a CVCV-reduplicant (1) and a $\mathrm{C} \varepsilon$-reduplicant (2). The prefix /mə-/ is a verb marker. Reduplicants are marked with underlines for CVCV-reduplicants and double underlines for $\mathrm{C} \varepsilon$ reduplicants.

(1) CVCV-reduplication (Josephs 1990)

\section{unreduplicated form}

melo? əd

metenəl

məsú?əd reduplicated form

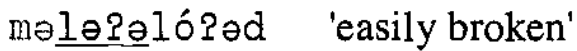

mətənətźnəl 'keep coming down'

məsə?ə⿻sú?əd 'always talk harshly'

(2) C $\varepsilon$-reduplication (Josephs 1990)

unreduplicated form

$\begin{array}{ll}\text { mətəgói } & \text { 'be talked to' } \\ \text { məsulául } & \text { 'sleepy' } \\ \text { mə?úPəp } & \text { 'cloudy' }\end{array}$

\section{reduplicated form}

metztəgói 'easy to talk to'

meşsulául 'kind of sleepy'

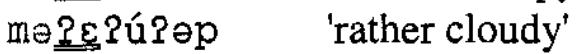

McCarthy and Prince (1994) have argued that partial reduplication can be described without using templates. Because faithfulness requirements on inputoutput correspondence do not apply to the reduplicant, what emerges in the reduplicant is the least marked structure, as defined by the phonological constraints of the language.

Languages that have different reduplicative morphemes with different shapes appear to be problematic for this claim. However, Urbanczyk (1999) has claimed that in a language which has multiple reduplications, the reduplicative morphemes are categorized as either roots or affixes and the two reduplicative morphemes are realized differently because faithfulness requirements on roots are stronger than general faithfulness requirements. Therefore, according to this claim, root reduplicants have more faithful structures than affix reduplicants where the shape of reduplicants differs.

If Urbanczyk's claim is correct, we should be able to choose one of the Palauan reduplicant as a root and the other as an affix. When the Roor MAX BR dominates some markedness constraints on the minimal word which dominates the general MAX BR, as ROOT MAX BR » markedness (minimal word) » Max BR, more segments are copied in the root reduplicant than in the affix reduplicant. Thus, the length of the reduplicants suggests that the CVCV-reduplicants are roots and $C \varepsilon$-reduplicants are affixes. When we look at the vowels in the reduplicants, however, the default vowel [ə] appears in the CVCV-reduplicants, but the more marked vowel $[\varepsilon]$ always appears in the $C \varepsilon$-reduplicants. The fixed segment $[\varepsilon]$ 
in the $C \varepsilon$-reduplicant appears to be problematic not only for the root/affix account, but for Alderete et. al's (1999) analysis of fixed segments in reduplication, as well. Alderete et. al argue that phonologically fixed segments in reduplicants represent the emergence of the unmarked (TETU). Thus, the fixed segment of Palauan reduplicants should be the default vowel [ə], but in fact, the fixed segment in the $\mathrm{C} \varepsilon$-reduplicant is $[\varepsilon]$.

In this paper, $I$ argue that this apparent problem is accounted for by the interaction of constraints. For the fixed segment $[\varepsilon]$ in $\mathrm{C} \varepsilon$-reduplication, $\mathrm{I}$ argue that $[\varepsilon]$ is the second least marked vowel in Palauan, which appears when the default vowel [ə] cannot appear. I show that the Palauan facts are not only consistent with the proposals of Urbanczyk (1999) and Alderete et. al (1999), but they actually provide support of their claims. In the following section, I discuss Urbanczyk's (1999) arguments concerning RooT faithfulness in reduplication and possible asymmetries between affix reduplicants and root reduplicants. In Section 3, I introduce Palauan reduplication and discuss Finer's (1986) observations on the resulting state verb (RSV) form. I show that the RSV forms support the classification that $\mathrm{C} \varepsilon$-reduplicants are affixes, and CVCV-reduplicants are roots. In Section 4, I discuss the shape and vowel quality of the two reduplicants. The CVCV-reduplicant has three variants: $\mathrm{C} ə \mathrm{C} ə, \mathrm{C} ə \mathrm{C}$ and $\mathrm{CV}, \mathrm{I}$ explain this variation, illustrating why [ə] appears in the first two variations. Then, I discuss the shape and vowel quality of the $\mathrm{C} \varepsilon$-reduplicant, arguing that the fixed segment $[\varepsilon]$ in $C \varepsilon$-reduplication is a special case of TETU. I show that root faithfulness constraints are crucial in determining the shape and vowel quality of the reduplicants. Section 5 is the conclusion.

\section{Root/Affix Asymmetries}

Steriade (1995) pointed out that roots allow more marked structure than affixes. Beckman (1997) translated this observation into correspondence theory, proposing two types of correspondence relations: general correspondence and restricted correspondence, including root faithfulness constraints. These faithfulness constraints may require roots to be more faithful than affixes.

Urbanczyk (1999), examining reduplication in Lushootseed, argued that interaction of ROOT faithfulness constraints on base-reduplicant (ROOT BR) faithfulness, general faithfulness constraints, and markedness constraints explains the realization of two types of reduplication. When a ROOT BR faithfulness constraint dominates some markedness constraint, the root reduplicant can have the marked structure. However, Root BR faithfulness constraints do not say anything about the affix reduplicant. So, if the markedness constraint which is dominated by the ROOT BR faithfulness constraint dominates the general BR faithfulness constraints, the marked structure cannot appear in the affix reduplicant and we get two distinct shapes of reduplicants. Following is her Lushootseed examples. 
(3) a. Lushootseed Distributive (DIST) Reduplication (Urbanczyk 1999) root reduplication

\begin{tabular}{|c|c|c|c|}
\hline & 'fly' & $\underline{s a ́ q}^{\text {w }}$ saq $^{\text {w }}$ & 'fly here and there' \\
\hline & fo & jósješsəd & 'feet' \\
\hline & 'young man" & lég" $\operatorname{ləg}^{\mathrm{w}}$ əb & 'young men' \\
\hline
\end{tabular}

\begin{tabular}{|c|c|c|c|}
\hline root & & reduplicati & \\
\hline Pálial & 'house" & Páralial & 'hut' \\
\hline ǰósəd & 'foot" & y̌íǰsad & 'little foot" \\
\hline təd ${ }^{2} i l$ & 'lie in bed" & títəd ${ }^{z} i l$ & 'lie down for a little while' \\
\hline
\end{tabular}

In Lushootseed, [ə] in the base is preserved in the DIST reduplicant with stress as [ó], but it cannot appear in the DIM reduplicant, which has the stressed default vowel [í]. Urbanczyk analyzes the DIST reduplicants as roots and the DIM reduplicants as affixes. Because the ROOT BR-faithfulness constraint (ROOT Ident BR) dominates the markedness constraint *[ó], which bans stressed schwas, [é] can appear in the root reduplicants, but not in the affix reduplicants.

(4) a. Lushootseed DIST (root) reduplication

\begin{tabular}{|c|c|c|c|}
\hline $\mathrm{RED}_{\text {root }} /$ / jəsəd/ & $\begin{array}{l}\text { ROOT IDENT } \\
\text { BR }\end{array}$ & *[ó] & IDENT BR \\
\hline ๙a. y̌śs jesəd & & (1) & \\
\hline b. jús ǰəsəd & $* !$ & 1 & $*$ \\
\hline
\end{tabular}

b. Lushootseed DIM (affix) reduplication

\begin{tabular}{|c|c|c|c|}
\hline 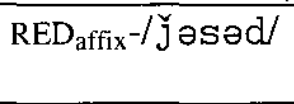 & $\begin{array}{l}\text { ROOT IDENT } \\
\text { BR }\end{array}$ & *[ó] & IDENT BR \\
\hline a. J̌áǰəsəd & & $* !$ & 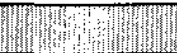 \\
\hline ob. jújəsəd & & & (1) \\
\hline
\end{tabular}

The difference in the morphological status of DIST and DIM reduplicants accounts for the occurrence of two types of reduplication in Lushootseed.

This analysis has one important implication. Both RoOT BR faithfulness constraints and general BR faithfulness constraints require the root reduplicant to be identical to the base. However, only general BR faithfulness constraints require the affix reduplicant to be identical with the base. Therefore, root reduplicants can be more faithful to the base than affix reduplicants. Furthermore, this analysis implies that root reduplicants can have more marked structure than affix reduplicants, but not vice versa.

If one reduplicant is an affix and the other a root in Palauan, we predict that root reduplicants will be more faithful and will allow more marked structures than affix reduplicants. In the next section, I examine the question whether Palauan reduplications are consistent with these claims. 


\section{Two types of Reduplication}

\subsection{Palauan Reduplication}

Palauan is a Western Malayo-Polynesian language, spoken in the Republic of

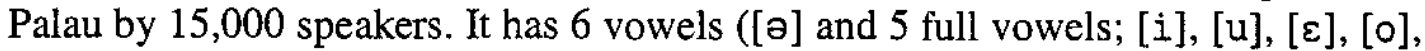
and [a]). [ə] is the default vowel and it cannot bear stress (Wilson 1972). As shown above, Palauan has two types of reduplication. The CVCV-type has several variants, namely $\mathrm{C} ə \mathrm{C} ə, \mathrm{C} ə \mathrm{C}$, and $\mathrm{CV}{ }^{1}$

(5) CVCV-reduplication (Josephs 1990)

a. $C ə C$ - form

unreduplicated form

mar ́́bək 'grope at'

məsú?əd 'talk harshly'

b. CəC-form

\section{unreduplicated form}

inerám 'be mixed'

məsónde 'break'

c. $C V$-form

$$
\begin{array}{ll}
\text { unreduplicated form } \\
\text { məฤióklə } & \text { 'be cooked' } \\
\text { məsúub } & \text { 'get studied' }
\end{array}
$$

reduplicated form

merəbər ćbək 'grope around'

mesə?əsú?əd 'always talk harshly'

reduplicated form

merəmrám 'easy to mix'

mesənsóndə 'keep breaking'

reduplicated form

məniniókle 'easy to cook'

mesusúub 'easy to study'

In most cases, we can predict which form appears from the shape of the base form. In $\mathrm{C} \varepsilon$-reduplication, the reduplicant always consists of [ $\varepsilon]$ and a copy of the first consonant of the root.

\begin{tabular}{|c|c|}
\hline Yój & 'easu to talk to' \\
\hline ใย?úu & 'fairy shady' \\
\hline 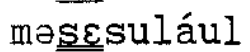 & 'kind of sleepy' \\
\hline
\end{tabular}

(6) CE-reduplication (Josephs 1990)

$\begin{array}{ll}\text { unreduplicated form } \\ \text { mətəgói } & \text { 'be talked to' } \\ \text { mə?úu } & \text { 'shady' } \\ \text { məsulául } & \text { 'sleepy' }\end{array}$

Note that the default vowel [ə] does not appear, but the more marked vowel $[\varepsilon]$ appears in the $\mathrm{C} \varepsilon$-reduplicant.

\subsection{The Resulting Stative Verb (RSV)-form}

Finer (1986) observes that the resulting state verb (RSV) marker is realized differently in CVCV-reduplication and $\mathrm{C} \varepsilon$-reduplication. In the unreduplicated form, the RSV marker /-1- /appears just after the first consonant of the root.

(7) RSV form: RSV morpheme /-1-/ + root (Finer 1986, ${ }^{2}$ Josephs 1990)

\begin{tabular}{ll}
\multicolumn{2}{l}{ simple form } \\
bóes & 'gun' \\
yábək & 'planing' \\
káud & 'dam' \\
Iźdəs & 'path'
\end{tabular}

RSV form

blóes 'shot'

Đlábak 'planed'

kláud 'dammed'

$11 \varepsilon \dot{d e s}$ 'stretched' 
When the RSV infix /-I-/ appears within the reduplicated forms, the CVCVreduplication and $\mathrm{C} \varepsilon$-reduplication show different patterns. In the CVCVreduplicated form, the RSV morpheme appears after the first consonant of the reduplicant. In the $\mathrm{C} \varepsilon$-reduplicated form, it appears after the first consonant of the base.

(8) RSV CVCV-reduplicated form (Josephs 1972, Finer 1986)
RSV unreduplicated form
RSV reduplicated form
$\begin{array}{ll}\text { ylábək } & \text { 'ironing' } \\ \text { blíis } & \text { 'filter' }\end{array}$
nI ləbə̧ábək 'scraped all over'
blibíi? 'sorted out by type'

(9) RSV CE-reduplicated form (Josephs 1972, Finer 1986)
RSV unreduplicated form
RSV reduplicated form
Đləmúl : $\theta$ 'cut'
bleóp 'shaped'
nع Iəmúl: : $\theta$ 'not well cut'

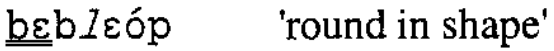

Given that CVCV-reduplicants are roots and $\mathrm{C} \varepsilon$-reduplicants are affixes, we can generalize the pattern in (8)-(9); the RSV affix appears after the first consonant of the first root. Finer's (1986) observations on the morphological differences of the two reduplications are then captured as a result of the root/affix asymmetry. I propose the following morphological structures for unreduplicated and reduplicated forms: ${ }^{3}$

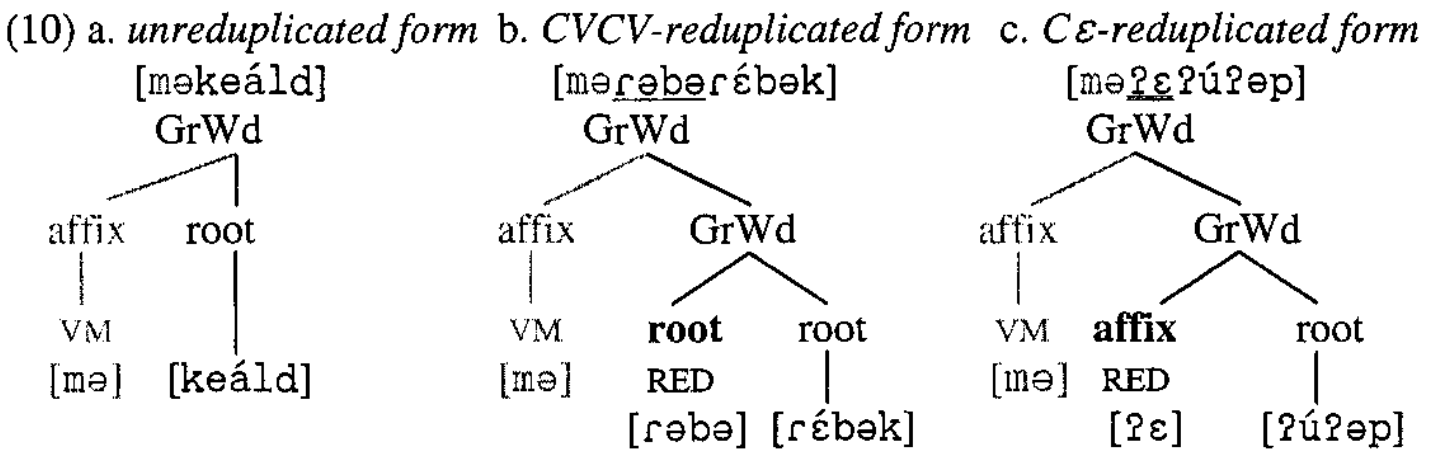

In the unreduplicated RSV form [ $k l e a$ ld], the RSV marker /-1-/ appears after the first consonant. In the CVCV RSV reduplicated form [ 0 lobopábək], the RSV marker appears after the first consonant of the first root. In the $\mathrm{C} \varepsilon$-reduplicated

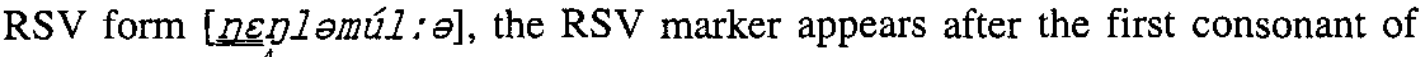
the root (base). ${ }^{4}$

\section{Apparent Problem: Vowel Quality}

So far, I have argued that the CVCV-reduplicants are roots and the $\mathrm{C} \varepsilon$ reduplicants are affixes. Urbanczyk (1999) argues that the root reduplicant may have more marked structure than the affix reduplicant. This claim implies that the $\mathrm{C} \varepsilon$-reduplicant should have a less marked structure than the CVCV-reduplicants. 
However, the least marked vowel (default vowel) [ə] appears in the CVCVreduplicants, but it never appears in the $C \varepsilon$-reduplicants. Further, the fact that the

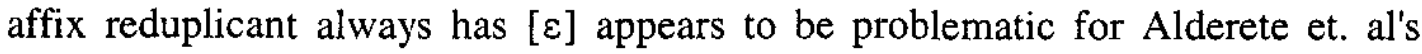
(1999) analysis of phonological fixed segments, which argues that the fixed segments in the reduplicants should be the default vowel and should be in the TETU condition.

In this section, I argue that the $\mathrm{C} \varepsilon$-reduplicants have less marked structure than the CVCV-reduplicants and propose that $[\varepsilon]$ is the second least marked vowel, which appears as a TETU effect when the default vowel [e] cannot appear. I first discuss CVCV-reduplication and then discuss $\mathrm{C} \varepsilon$-reduplication.

\subsection{CVCV-reduplication and its Variations}

As shown above, $\mathrm{CVCV}$-reduplication is realized in three different forms: $\mathrm{C} ə \mathrm{C} ə$, $\mathrm{C} \ominus \mathrm{C}$, and $\mathrm{CV}$. The examples are repeated below:

(11) a. CəCə-form

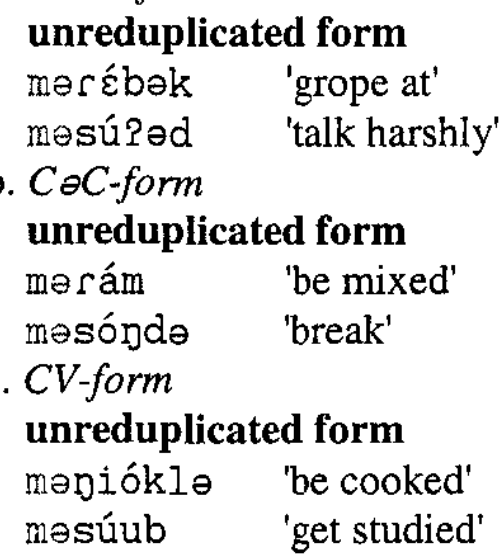

\begin{tabular}{|c|c|}
\hline \multicolumn{2}{|c|}{ reduplicated form } \\
\hline mərəbar $\underline{\text { b bək }}$ & 'grope around' \\
\hline məsə?əsú?əd & 'always talk harshly' \\
\hline \multicolumn{2}{|c|}{ reduplicated form } \\
\hline meromrám & 'easy to mix' \\
\hline mesəansónde & 'keep breaking' \\
\hline \multicolumn{2}{|c|}{ reduplicated form } \\
\hline meniniókle & 'easy to cook' \\
\hline mesusúub & 'easy to study' \\
\hline
\end{tabular}

When the first two syllables of the base are CV.CV(C)., the reduplicant is Cə.Cə., as (11a). When the first syllable of the base is CVC, this syllable is duplicated with the vowel reduced to [ $\ominus]$, as $\mathrm{C} \ominus \mathrm{C}$ in $(1 \mathrm{~b})$. When the first two syllables of the base are $\mathrm{CV} . \mathrm{V}(\mathrm{C})$, then the reduplicant is $\mathrm{CV}$, copying the first consonant and either the first or second vowel, as (11c). ${ }^{5}$

To capture this close relation between the shape of the reduplicant and vowel quality, I propose that the default vowel $[\theta]$ and coda each carry one mora, while

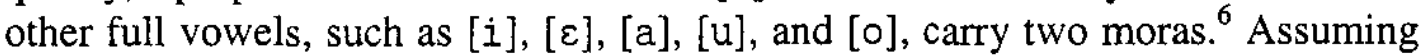
that the root-reduplicant must be a foot (ROOT=FOOT) and a foot contains two moras (FT-BN $(\mu)$ ), the CVCV-reduplicant consists of two moras. To make the reduplicant bi-moraic, there are two options: copying two syllables, while reducing the full vowel to [ə], or copying one syllable while keeping the full vowel. So, the possible candidates for $/ \mathrm{m}+R E D_{\text {root }}+r \varepsilon$ col $/$ would be

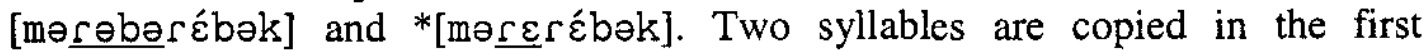
candidate and only one syllable is copied in the second. Since [mərəbərर́Eək] is the correct form, the elements of the base must be copied as far as possible. These requirements on the reduplicant are translated into the following constraints: 
(12) a. FT-BN $(\mu)$ : Every foot must have exactly two moras.

b. ROOT=FOOT: Every root must contain a foot.

c. PARSE- $\sigma$ : Every syllable must be parsed into a foot.

d. RoOT MAX BR: Every element of the base has a correspondent in the root reduplicant.

The following tableau illustrates how these constraints work. The numbers under the segments indicate correspondence relations.

\begin{tabular}{|c|c|c|c|c|c|}
\hline 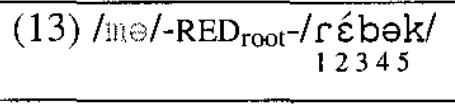 & $\begin{array}{l}\text { MAX IO, } \\
\text { IDENT IO }\end{array}$ & $\begin{array}{l}\text { ROOT } \\
=\text { FOOT }\end{array}$ & $\begin{array}{l}\text { FT-BN } \\
(\mu)\end{array}$ & $\begin{array}{l}\text { ROOT } \\
\text { MAX BR }\end{array}$ & $\begin{array}{l}\text { PARSE- } \\
\sigma \\
\end{array}$ \\
\hline 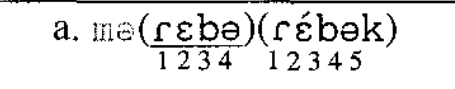 & & & $* * !$ & $\mathbb{x}$ & N \\
\hline b. $m e\left(\frac{\Gamma \varepsilon}{12}\right)\left(\frac{\mathrm{b} \partial \mathrm{k}}{345}\right)(\underset{12345}{\Gamma \varepsilon \mathrm{b} \rho \mathrm{k}})$ & & $* !$ & 4 & & *at \\
\hline c. $\operatorname{me}\left(\frac{\Gamma \varepsilon}{12}\right)(\underset{12345}{(r \varepsilon b a k)}$ & & & $*$ & $* * * !$ & * \\
\hline 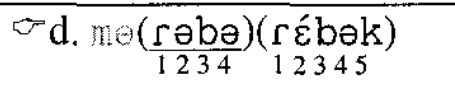 & & & $*$ & $*$ & * \\
\hline
\end{tabular}

The candidate (13a) is ruled out for two violations of FT-BN $(\mu)$ because the reduplicant has three moras: two for $[\varepsilon]$ and one for [ə]. (13b) is ruled out by ROOT=FOOT, since the reduplicant equals two feet, not one foot. While the reduplicants in both (13c) and (13d) satisfy FT-BN $(\mu)$, (13d) wins because of fewer violations of ROOT MAX BR.

When the first syllable of the base has a coda, the reduplicant is realized with the $\mathrm{C} ə \mathrm{C}$ form. Given that the coda is moraic in Palauan (Wilson 1972), the grammar in (13) predicts the $\mathrm{C} ə \mathrm{C}$ form, as shown in (14).

\begin{tabular}{|c|c|c|c|c|c|}
\hline (14) /m@/-RED root $_{123} /$ rám $_{12}$ & $\begin{array}{l}\text { MAX IO, } \\
\text { IDENT IO }\end{array}$ & $\begin{array}{l}\text { ROOT } \\
=\text { FOOT }\end{array}$ & $\begin{array}{l}\text { FT-BN } \\
(\mu)\end{array}$ & $\begin{array}{l}\text { ROOT } \\
\text { MAX BR }\end{array}$ & PARSE- $\sigma$ \\
\hline a. ne $\left.\frac{(\text { ram }}{123}\right)($ rám $)$ & & & $* * !$ & & $*$ \\
\hline b. me $\frac{(r a)}{12}\left(r_{123} a ́ m\right)$ & & & $*$ & $* !$ & 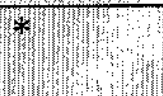 \\
\hline$\sigma_{c . ~ m e}\left(\frac{r \partial m}{123}\right)\left(r_{123} \operatorname{cá}^{2}\right)$ & & & $*$ & & \\
\hline
\end{tabular}

In (14a), every element in the base is copied in the reduplicant. Since the full vowel [a] carries two moras and the coda [m] carries one mora, the reduplicant has three moras, violating $\mathrm{Ft}-\mathrm{Bn}(\mu)$. The reduplicants in (14b) and (14c) satisfy $\mathrm{Ft}-\mathrm{Bn}(\mu)$. Since more elements in the base are copied in $(14 \mathrm{c})$ than in $(14 \mathrm{~b})$, the candidate $(14 \mathrm{c})$ wins.

In the CV-form, such as [məpinióklə], the first syllable of the base is CV and the second syllable starts with vowel. Since the reduplicant must have two 


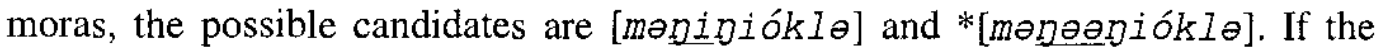
ONSET constraint (Syllable must have an onset) is ranked between MAX IO and RoOT MAX BR, the onsetless syllable appears only in the reduplicant. The grammar for [məninióklə], is shown in the following tableau:

\begin{tabular}{|c|c|c|c|c|c|}
\hline 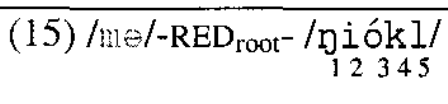 & $\begin{array}{l}\text { MAX IO, } \\
\text { IDENT IO }\end{array}$ & $\begin{array}{l}\text { ROOT } \\
=\text { FOOT }\end{array}$ & $\begin{array}{l}\text { FT-BN } \\
(\mu)\end{array}$ & ONSET & $\begin{array}{l}\text { ROOT } \\
\text { MAX BR }\end{array}$ \\
\hline 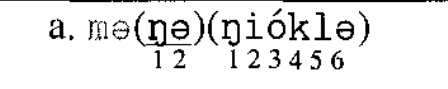 & & & $* *$ ! & $*$ & $* * * *$ \\
\hline 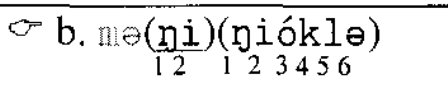 & & & $*$ & $*$ & $* * * *$ \\
\hline 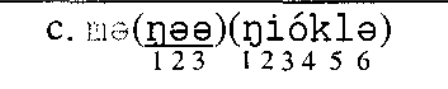 & & & * & $* * !$ & $* * *$ \\
\hline 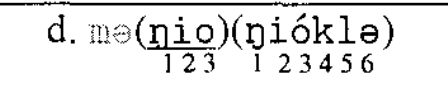 & & & $* * !$ & ** & 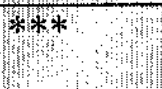 \\
\hline
\end{tabular}

In (15b) and (15c), the reduplicant has two moras. (15c) has an onsetless syllable in the reduplicant. So, the constraint ONSET chooses (15b) over (15c). The introduction of ONSET does not affect (13) and (14), since every relevant syllable has an onset.

\section{2. $C \mathcal{E}$-reduplication}

I have argued that CVCV-reduplication is root-reduplication and that the reduplicant sometimes has the least marked vowel [ə]. ${ }^{7}$ Urbanczyk (1999) argues that affix reduplicants tend to be less marked than root reduplicants because of root faithfulness constraints. Therefore, Urbanczyk's analysis predicts that no vowel besides [ə] can appear in affix reduplicants. Alderete et. al (1999) also argue that the phonological fixed segment must be the default segment. Thus the fixed segment in the affix reduplicant should be [ə]. However, the examples in (16) show that this is not the case.

(16) CE-reduplication (Josephs 1990)

$\begin{array}{ll}\text { unreduplicated form } \\ \text { me } u \text { səp } & \text { 'cloudy' } \\ \text { metəgói } & \text { 'be talked to' } \\ \text { mesódəl } & \text { 'tear' } \\ \text { metoiáklə } & \text { 'tall' }\end{array}$

\begin{tabular}{|c|c|}
\hline eut & \\
\hline 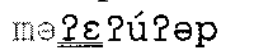 & 'rather cloudy' \\
\hline hetztegói & 'easy to talk' \\
\hline masesódəl & 'easily torn' \\
\hline etztoiákle & 'fairly tall' \\
\hline
\end{tabular}

The vowel in the $\mathrm{C} \varepsilon$-reduplicant is always $[\varepsilon]$, which is more marked than $[\ominus]{ }^{8}$

Because of the constraint ROOT=FOOT, the base is a foot. If the left edge of the affix reduplicant must coincide with the left edge of the foot (Align $\mathrm{L}$ (affix $\mathrm{RED}_{\mathrm{RE}}$, foot)), the affix reduplicant must be a foot with two moras. The possible reduplicants for the base [?úpəp] are then $\left.[? \varepsilon],{ }^{*}\left[\rho_{\ominus}\right\}\right]$, and $*[? \ominus ? \ominus]$. Since the $\mathrm{C} \varepsilon$-reduplicant has affix status, ROOT MAX BR is irrelevant here. When we compare $[? \varepsilon]$ and $*[? \curvearrowright ?]$, we notice that the reduplicant $[? \varepsilon]$ does not have coda,

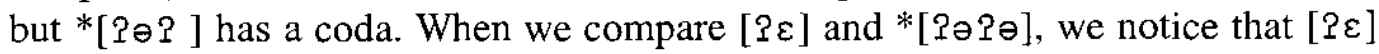


has fewer syllables. Thus, the constraint which bans codas and the constraint which limits the number of syllables work crucially in $\mathrm{C} \varepsilon$-reduplication.

(17) a. No CoDA: Codas are not allowed.

b. NO STRUC- $\sigma$ : Syllable structure is not allowed.

(Kager 1999)

(Prince and Smolensky 1993)

Since the correct reduplicant is one syllable without a coda, No STRUC- $\sigma$ and No CODA dominate MAX BR. The ranking of constraints is shown in the following tableau.

\begin{tabular}{|c|c|c|c|c|c|}
\hline $\begin{array}{c}\text { (18)/me/-RED } \text { affix }^{-} \\
\text {/ } \mathrm{qú} \text { ?əp/ }\end{array}$ & $\begin{array}{l}\text { FT- } \\
\text { BN }(\mu)\end{array}$ & $\begin{array}{l}\text { ROOT } \\
\text { MAX BR }\end{array}$ & $\begin{array}{l}\text { No } \\
\text { CODA } \\
\end{array}$ & $\begin{array}{l}\text { No } \\
\text { STRUC- } \sigma\end{array}$ & $\begin{array}{l}\text { Max } \\
\text { BR }\end{array}$ \\
\hline a. $m \ominus($ & $*$ & & $* * !$ & 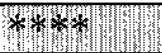 & 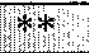 \\
\hline 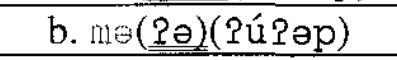 & $* * !$ & 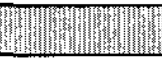 & 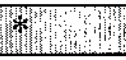 & *6** & $1 * *$ \\
\hline 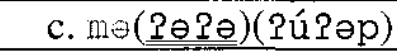 & $*$ & & $*$ & $* * * * * !$ & 4 \\
\hline 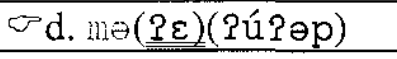 & $*$ & & $*$ & $* * * *$ & $* * *$ \\
\hline
\end{tabular}

The candidate (18a) violates No CODA twice. The reduplicant in (18b) has only one mora. Thus, they are ruled out. The reduplicants in (18c) and (18d) have two moras. Since ROOT MAX BR does not apply to the affix reduplicant, No STRUC- $\sigma$ chooses (18d). Notice that ROOT MAX BR dominates the markedness constraints No STRUC- $\sigma$ / No CODA. This ranking enables a coda and two syllables in the root reduplicant. At the same time, No STRUC- $\sigma$ and No CODA dominate (general) MAX BR, so this grammar disallows [ə] to appear in the affix reduplicant.

So far, the shape of the $\mathrm{C} \varepsilon$-reduplicants and the non-occurrence of [ə] are accounted for, but it is not yet explained why the vowel in the reduplicant should always be $[\varepsilon]$. I propose that $[\varepsilon]$ is the second least marked vowel in Palauan and it appears under the TETU condition in which the default vowel [ə] cannot appear. [ə] does not have place features, such as [-back], [+high], [+low], or [+round]. Thus $[\ominus]$ never violates featural markedness constraints, such as $*[-$ $\mathrm{B}($ ack $)], *[+\mathrm{H}(\mathrm{igh})], *[+\mathrm{L}(\mathrm{ow})]$ and $*[+\mathrm{R}$ (ound) $]$. $[\varepsilon]$, on the other hand, has the feature [-back], violating *[-B]. Thus, $[\varepsilon]$ is more marked than $[\vartheta]$. However, as we saw above, the default vowel [ə] cannot appear in the affix reduplicant. If the featural markedness constraints are ranked as *[+H],*[+L],*[+R]»*[-B], then the appearance of $[\varepsilon]$ is considered as a TETU effect. This is shown in the following tableau. The candidates in $(18 \mathrm{a})$, and (18d) are repeated as (19a), and (19b) respectively. 


\begin{tabular}{|c|c|c|c|c|c|c|}
\hline 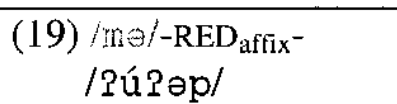 & $\begin{array}{l}\text { No } \\
\text { CODA }\end{array}$ & $*[+\mathrm{R}]$ & $*[+\mathrm{L}]$ & $*[+\mathrm{H}]$ & $*[-\mathrm{B}]$ & $\begin{array}{l}\text { MAX } \\
\text { BR }\end{array}$ \\
\hline a. me(ใə?)(ใú?əp) & $* * !$ & *19 & $\sqrt{13}$ & m & tim & ** \\
\hline$\sigma$ b. $m a(? \varepsilon)($ ใú $\vartheta \ni$ ) & * & $*$ & & & * & $* * *$ \\
\hline 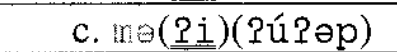 & $*$ & $*$ & & $* !$ & * & k** \\
\hline d. $n \ominus($ ?a)(?ú & $*$ & * & $* !$ & The & (n) & (n) \\
\hline 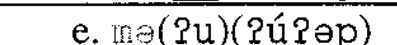 & * & $* * !$ & 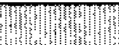 & & 升其 & $+x+x$ \\
\hline
\end{tabular}

Among full vowels, $[\varepsilon]$ is the least marked vowel, and hence $(19 b)$ is the output form. This tableau shows that the emergence of $[\varepsilon]$ in the $C \varepsilon$-reduplicant is a special case of TETU and it indicates that a non-default vowel can be the phonological fixed segment under some special conditions.

Note that even if the first syllable of the base is $[ə],[\varepsilon]$ appears in the affix reduplicant.

(20) unreduplicated form

$\begin{array}{ll}\text { mePəsán } & \text { 'busy' } \\ \text { mePəláod } & \text { 'content' } \\ \text { merə?órə? } & \text { 'steal' }\end{array}$

reduplicated form

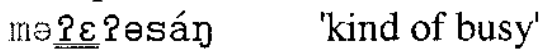

me?

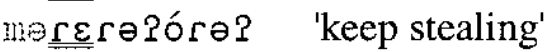

The realization of $[\varepsilon]$ in the affix reduplicant can be explained with the above

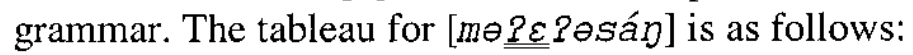

\begin{tabular}{|c|c|c|c|c|c|c|c|}
\hline $\begin{array}{c}\text { (21)/my/-RED } \text { affix }^{-} \\
\text {/Pəsay/ }\end{array}$ & $\begin{array}{l}\text { FT-BN } \\
(\mu)\end{array}$ & $\begin{array}{l}\text { No } \\
\text { CODA }\end{array}$ & $*[+\mathrm{R}]$ & $*[+\mathrm{L}]$ & $*[+\mathrm{H}$ & $*[-\mathrm{B}]$ & $\begin{array}{l}\text { MAX } \\
\text { BR }\end{array}$ \\
\hline a. me( $(\underline{\underline{\text { Pə}}})($ Pəsán) & $* * !$ & In & & 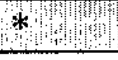 & min & & $* * *$ \\
\hline 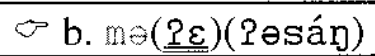 & $*$ & $*$ & & $*$ & & 14 & *k*k \\
\hline c. me(Pi)(?esán) & $*$ & $*$ & & $*$ & $* !$ & * & $* x$ \\
\hline d. me(Pa)(?әsán) & $*$ & * & & $* * !$ & $y^{4} \quad 4$ & & $*^{*+*}$ \\
\hline e. $m \ominus(\underline{\underline{\underline{ }} u})($ Pəsán $)$ & $*$ & $*$ & $* !$ & $|x|$ & $*$ & & *** \\
\hline
\end{tabular}

This tableau shows that [ə] cannot appear in the reduplicant and instead, the next least marked vowel $[\varepsilon]$ appears in the reduplicant.

In this analysis, $[\varepsilon]$ is not specified in the input, yet the grammar guarantees the realization of $[\varepsilon]$. This grammar shows that the phonological fixed segment can be a non-default vowel, but it is still one case of TETU. Thus, the realization of the fixed segment $[\varepsilon]$ in Palauan affix reduplication is consistent with Alderete et. al's (1999) analysis of phonological fixed segments. Further, the affix reduplicant is less marked than the root reduplicant, since it copies fewer segments. So, the root-affix asymmetries in the shape and vowel quality follow the implications of Urbanczyk's (1999) analysis. ${ }^{9}$ 


\section{Conclusion}

In this paper, I identified the Palauan CVCV-reduplicant as a root and the $\mathrm{C} \varepsilon$ reduplicant as an affix. While the affix reduplicants have a fixed non-default vowel, which looks problematic for Urbanczyk's (1999) claim and Alderete et. al's (1999) analysis, I showed the emergence of a non-default vowel is also a special case of TETU and the root reduplicants are more faithful to the base than the affix reduplicants due to a root faithfulness constraint.

This analysis implies that there are only two types of reduplicant in each language. While Palauan has $\mathrm{C} \varepsilon \mathrm{CVCV}$ reduplication, in addition to $\mathrm{C} \varepsilon$ reduplication and CVCV-reduplication, this case can be considered as a combination of the two reduplicative morphemes. However, some languages, such as Korean, have more than two types of reduplication (Cho 1999). These interesting cases need further research.

\section{Endnotes}

ACKNOWLEDGEMENT: I am grateful to Christina Y. Bethin, Daniel L. Finer, three AFLA reviewers and specially to Ellen Broselow for helpful suggestions and comments. I also thank the audience at the Long Island Sound Meeting 2003 (Stony Brook) and at the $11^{\text {th }}$ Annual Meeting of the Austronesian Formal Linguistic Association (Berlin) for useful discussion.

1. Zuraw (2001) observes CCə form as well, such as [01-dmə-dúm] (keep bobbing to surface of water). It seems that this is one version of the $\mathrm{C} ə \mathrm{C}$ variation. Zuraw argues that this is mostly conditioned by the surrounding consonants. This pattern is not covered in my analysis.

2. All data discussed by Finer (1986) are originally from Josephs (1975), McManus (1977) or Wilson (1972).

3. While Finer (1986) proposes the structures in (i), I propose the structures in (10) to apply Urbanczyk's (1999) analysis.

(i) a. unreduplicated form [məkeáld]

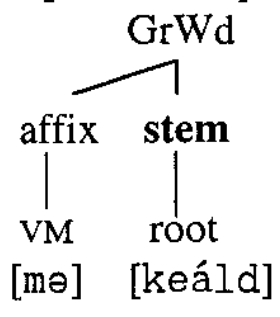

b. CVCV-reduplicated form [mərəbər $\tilde{\varepsilon}$ bək]

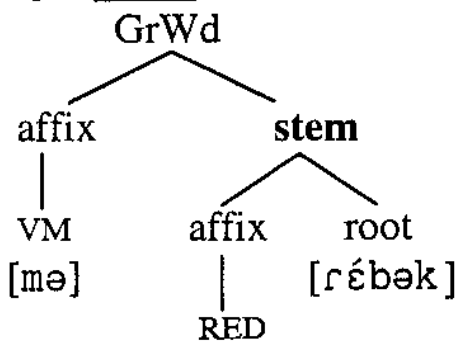

[rəbə] c. C $\varepsilon$-reduplicated form

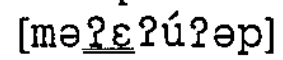

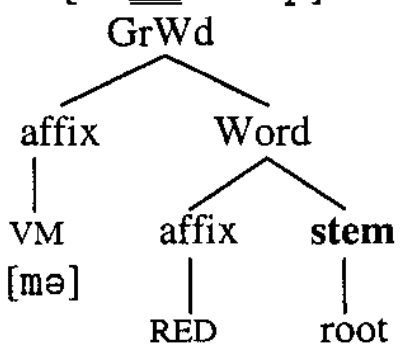

[?ع] [?ú?əp]

4. The RSV marker /-1-/ never appears at the left edge, and the left edge of the root is always aligned at the left edge of the prosodic word. At the same time, the $\mathrm{RSV}$ marker has to be just after the first consonant of the root. Therefore, the 
RSV affix is aligned as close to the left edge of the prosodic word as possible with the constraints in (i).

(i) a. ALIGN L (root, PrWd): The left edge of a root must coincide with the left edge of the prosodic word.

b. ALIGN L (RSV affix, PrWd): The left edge of the RSV affix must coincide with the left edge of the prosodic word.

When we look at the form [kleáld], we notice that the alignment requirement for the root is stronger than the alignment requirement for the RSV affix, favoring the affix inside the root. This indicates that ALIGN L (root, PrWd) dominates ALIGN L (RSV affix, PrWd), as shown in the tableau (ii).

\begin{tabular}{|c|c|c|}
\hline (ii) $/ 1 / / \mathrm{keáld} /$ & $\begin{array}{l}\text { ALIGN L } \\
\text { (root,PrWd) }\end{array}$ & $\begin{array}{l}\text { ALIGN L } \\
\text { (RSVaffix,PrWd) }\end{array}$ \\
\hline o. $[(\mathrm{k} l$ eáld $)]$ & & $\bar{\hbar}$ \\
\hline b. [(1keáld)] & *! & $4 n$ \\
\hline c. [(keáldl)] & & $\star \star \star \star \star !$ \\
\hline d. [(keláld)] & & **! \\
\hline
\end{tabular}

For the RSV CVCV-reduplicated forms, we need the constraint in (iii) which dominates the constraints in (ii). The tableau is given in (iv).

(iii) ALIGN R (root, PrWd): The right edge of a root must coincide with the right edge of the prosodic word.

\begin{tabular}{|c|c|c|c|}
\hline 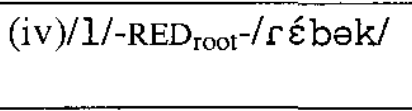 & $\begin{array}{l}\text { ALIGN R } \\
\text { (root,PrWd) }\end{array}$ & $\begin{array}{l}\text { ALIGN L } \\
\text { (root,PrWd) }\end{array}$ & $\begin{array}{l}\text { ALIGN L } \\
\text { (RSVaffix,PrWd) }\end{array}$ \\
\hline$\sigma a .[(I] \rho$ & $* * * * *$ & $* * * * *$ & * \\
\hline b. $[($ rəbə $)(r l \varepsilon ́$ bək $)]$ & - & 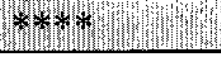 & 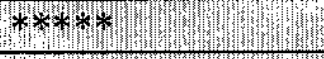 \\
\hline 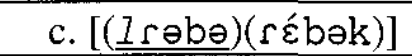 & $* * * * *$ & $* * * * * * !$ & \\
\hline
\end{tabular}

The same grammar explains the RSV C $\varepsilon$-reduplicated form.

5. It is not so clear which vowel is copied. Zuraw (2002) examines the vowel reduction and observes that the same vowel remains in the possessive form, in which vowel reduction takes place. So it seems there is a systematic way, but I do not see the mechanism of vowel reduction in the VV sequences.

6. If we assume that the full vowels have one mora and [ə] and codas do not carry any moras, we have to say that the foot can contain at most one mora for the $\mathrm{CV}$ case and we cannot exclude the reduplicant ${ }^{*} \mathrm{C} ə \mathrm{C} ə \mathrm{C}$ or ${ }^{*} \mathrm{CVC} ə \mathrm{C}$ or ${ }^{*} \mathrm{CVC}$. Further, the assumption that the coda does not have a mora fails to capture Wilson's (1972) observation on stress assignment.

7. When a word has a consonant cluster word finally, sometimes [ə] is inserted. 
(i) input

/dakt/

/mələPolb/

$/ \mathrm{kbokb} /$

/bsibs/

$\begin{array}{ll}\text { simple form } & \text { (Josephs 1975) } \\ \text { dákt } \theta & \text { 'fear' } \\ \text { mələ?ólbə } & \text { 'bother' } \\ \text { kpókpə } & \text { 'water' } \\ \text { psípsə } & \text { 'drill' }\end{array}$

Given that the epenthetic vowel is a default vowel (McCarthy and Prince 1994), $[ə]$ is the default vowel in Palauan.

8. Since affix reduplicants involve more marked segments than some forms of the root reduplicants, Urbanczyk (1999) mentions that Palauan is a case of morphological overwriting (Alderete et al. 1999). The input of the reduplicated

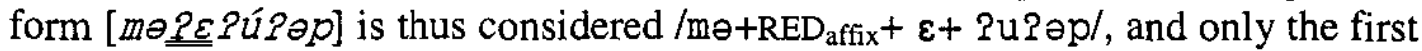
consonant of the base is copied. While the emergence of $[\varepsilon]$ is predicted, assuming $/ \varepsilon-/$ in the input considerably weakens the claim that we can dispense with templates for reduplicants (McCarthy and Prince 1994). So, rather than assuming $/ \varepsilon-/$ in the input, I propose an analysis in which realization of $[\varepsilon]$ is one instance of TETU in the text.

9. One of the reviewers pointed out that $[\varepsilon]$ appears in the TETU condition in the possessive form as well. The possessive suffix is $/-k /$ and the syllable which has this suffix always carries stress. When the noun stem ends with a consonant, the vowel $[\varepsilon]$ is inserted.

(i) underlying form

$\begin{array}{llll}\text { /bunal } & \text { 'flower' } & \text { [pupák] } & \text { 'my flower' } \\ \text { /nalək/ } & \text { 'child' } & \text { [paləkśk] } & \text { 'my child' }\end{array}$

Usually the inserted vowel is the least marked vowel. In Palauan, [ə] is the least marked vowel, but it cannot bear stress. So, the second least marked vowel $[\varepsilon]$ appears. Because the stress shifts to the last syllable in the possessive form, the vowel reduction takes place in the possessive form in the same way as with the CVCV-reduplication (Wilson 1972, Finer 1986, and Zuraw 2002).

(ii) a. simple form

$\begin{array}{ll}\text { yór } & \text { 'mouth' } \\ \text { bsílbs } & \text { 'drill' } \\ \text { sćss } & \text { 'garden' }\end{array}$

b. sáik 'laziness'

klakoád 'fight'

beróns 'dream'

\author{
possessed form (Josephs 1975, Finer 1986)

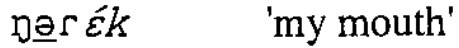 \\ bsębs $\varepsilon$ k 'my drill' \\ sọrśkk 'my garden' \\ sìk $\hat{\varepsilon} k$ 'my laziness' \\ klakod $\varepsilon$ k 'my fight' \\ berussék 'my dream'
}

The possessive suffix has stress, and the stressed vowel in the root is reduced. When the CVCV-reduplication and the possessives are compared, we notice that vowel reduction takes place in the unstressed foot. To account for these two cases uniformly, MAX IO and IDENT IO should be considered as faithfulness constraints only for the stressed foot (MAX IO IN STRESSED FOOT, IDENT IO IN STRESSED FOOT), and general MAX IO and IDENT IO must be ranked lower than other 
constraints. These constraints do not affect the elements in the base of reduplicated words, since the base itself is a stressed foot. The following is the tableau for the possessive form in (iia).

\begin{tabular}{|c|c|c|c|c|c|}
\hline (iii) $/$ nor $/+/ \mathrm{k} /$ & $\begin{array}{l}\text { MAX/IDENT IO } \\
\text { IN STRESSED } \\
\text { FOOT }\end{array}$ & $\begin{array}{l}\text { ROOT }= \\
\text { FOOT }\end{array}$ & $\begin{array}{l}\text { FT-BN } \\
(\mu)\end{array}$ & ONSET & $\begin{array}{l}\text { ROOT } \\
\text { MAX } \\
\text { BR }\end{array}$ \\
\hline 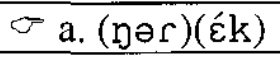 & & & $*$ & nt & \\
\hline b. $(\eta \circ r)(\varepsilon ́ k)$ & & & $* * !$ & 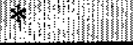 & \\
\hline c. $($ gər)(ák) & $* !$ & & & * & \\
\hline
\end{tabular}

The candidate in (iiib) is ruled out, since both feet have three moras each and it violates FT-BN $(\mu)$ twice. (iiic) is ruled out because the second foot (ék) has stress and it is not faithful to the input. In the winning candidate (iiia), the vowel in the root is reduced. This change is allowed, since the foot for the base is not stressed and MAX/IDENT IO IN STRESSED FOOT is satisfied.

In (iib), one vowel is deleted and another vowel remains without being reduced to [ə]. To explain this case, I have to assume the conjoined constraint [Max IO + Ident IO] (Smolensky 1993). This constraint is violated only if both Max IO and Ident IO are violated. It does not affect the tableau in (iii) because the correct form does not violate it.

\begin{tabular}{|c|c|c|c|c|c|}
\hline (iv)/saik/+/र́ḱk/ & $\begin{array}{l}\text { MAX/IDENT IO } \\
\text { IN STRESSED } \\
\text { FOOT }\end{array}$ & $\begin{array}{l}\text { ROOT }= \\
\text { FOOT }\end{array}$ & $\begin{array}{l}\text { [MAX IO + } \\
\text { IDENT IO] }\end{array}$ & $\begin{array}{l}\text { FT-BN } \\
(\mu)\end{array}$ & ONSET \\
\hline$\sigma$ a. $($ sik $)(\varepsilon ́ k)$ & & & & $* *$ & $*$ \\
\hline 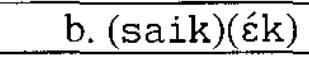 & & & & $* *$ & $* * !$ \\
\hline c. $(\mathrm{s} ə \mathrm{k})($ śk) & & & $* !$ & (I) & w \\
\hline
\end{tabular}

(iv b) has two onsetless syllables, namely $[i k]$ and [źk], violating ONSET twice. In the candidate (iv c), one of the vowels in the sequence is deleted, violating Max $I O$, and another vowel is reduced to [ə], violating Ident IO. Since this candidate violates both Max IO and Ident IO, it violates the conjoined constraint [MAX IO + IDENT IO]. Given this analysis, vowel reduction takes place to satisfy FT-BN $(\mu)$ in both possessive forms and reduplications.

\section{References}

Alderete, John D., Jill Beckman N., Laura Benua, Amalia Gnanadesikan E., JOHN MCCARTHY J., AND SUZANNE URBANCZYK. 1999. Reduplication with fixed segmentism. Linguistic Inquiry 30. 3, 327-364.

BECKMAN, JiLL N. 1997. Positional faithfulness. Amherst: University of Massachusetts Amherst dissertation. 
CHO, YounG-MEE Y. 1999. Optimality in Korean reduplication. Harvard Studies in Korean Linguistics 8, 73-87.

FINER, DANIEL L. 1986. Reduplication and verbal morphology in Palauan. The Linguistics Review 6, 99-130.

JOSEPHS, LEWIS S. 1975. Palauan reference grammar. Honolulu: University of Hawaii Press.

JOSEPHS, LEWIS S. 1990. New Palauan-English dictionary. Honolulu: University of Hawaii Press.

KAGER, RENÉ. 1999. Optimality theory. Cambridge: Cambridge University Press.

MCCARTHY, JOHN J., AND ALAN PRINCE. 1994. The emergence of the unmarked: optimality in prosodic morphology. Proceedings of the North East Linguistic Society (NELS) 24. 333-379.

McManus, EDwIN S. J. 1977. Palauan-English dictionary. Honolulu: University of Hawaii Press.

PRINCE, Alan. AND PAul SMOlensky. 1993. Optimality theory: Constraint interaction in generative grammar. Technical Report \#2 of the Rutgers Center for Cognitive Science, Rutgers: Rutgers University.

STERIADE, DONCA. 1995. Underspecification and markedness. The handbook of phonological theory, ed. by Goldsmith, John, 114-174. Oxford: Blackwell.

SMOLENSKY, PAUL. 1993. Harmony, markedness, and phonological activity. [ROA-87, http://ruccs.rutgers.edu/roa.html]

URBANCZYK, SUZANNE. 1999. Reduplicative size-segmentism correlations as root-affix asymmetries. ms. New Bruswick: Rutgers University,.

WILSON, HELEN. 1972. The phonology and syntax of Palauan verb affixes. Honolulu: University of Hawaii dissertation.

ZURAW, KIE. 2002. Vowel reduction in Palauan reduplications. Proceedings of AFLA 8.

Tomoko Kawamura

SUNY at Stony Brook

Department of Linguistics, SUNY at Stony Brook, NY 11794-4376,

U.S.A.

tkawamur@ic.sunysb.edu 